\title{
Complexes of Bis(Dialkyldithiocarbamato)Arsenic(II) with Alkyldithiocarbonates: Synthesis and Characterization
}

\author{
H.P.S. Chauhan*, Kavita Kori, N.M. Shaik and U.P. Singh \\ School of Chemical Sciences, Devi Ahilya University, Takshshila Campus, Khandwa Road, \\ Indore - 452 017, India \\ hpsc@rediffmail.com
}

\begin{abstract}
The reactions of $\left[\mathrm{R}_{2} \mathrm{NCS}_{2}\right]_{2} \mathrm{AsCl}$ with $\mathrm{KS}_{2} \mathrm{COR}$ ' in 1:1 molar ratio at room temperature readily gave mixed derivatives of the type $\left[\mathrm{R}_{2} \mathrm{NCS}_{2}\right]_{2} \mathrm{AsS}_{2} \mathrm{COR}$ ' [where, $\mathrm{R}=\mathrm{CH}_{3}$ and $\mathrm{C}_{2} \mathrm{H}_{5} ; \mathrm{R}^{\prime}=\mathrm{Et}, \mathrm{Pr}^{\mathrm{n}}, \mathrm{Pr}^{\mathrm{i}}, \mathrm{Bu}^{\mathrm{n}}$ and $\mathrm{Bu}^{\mathrm{i}}$ ]. These derivatives are yellow crystalline solids. All these newly synthesized derivatives are soluble in common organic solvents like benzene, chloroform, carbondisulphide, acetone and dichloromethane etc. These derivatives have been characterized by melting points, elemental analysis ( $\mathrm{C}, \mathrm{H}, \mathrm{N}, \mathrm{S}$ and $\mathrm{As})$ as well as spectral IR, NMR $\left[{ }^{1} \mathrm{H}\right.$ and $\left.{ }^{13} \mathrm{C}\right]$ studies. On the basis of these studies tentative structures for these derivatives have been proposed.
\end{abstract}

Keywords: Arsenic; dialkyldithiocarbamate; alkyldithiocarbonate; IR spectra; ${ }^{1} \mathrm{H}$ and ${ }^{13} \mathrm{C}$ NMR spectra.

\section{INTRODUCTION}

The structural diversities in dialkyldithiocarbamates /1-17 /and alkyldithiocarbonates /15-23/ ligands is quite remarkable due to their bonding/coordination patterns with transition as well as main group metals /I9,15-18/. Although a number of inorganic arsenic(III) dithiolates have been isolated and several of them characterized fully by single crystal $x$-ray analysis $/ 1,5,12,15-19,21-23 /$, relatively less attention has been paid to mixed I,I-dithiolato ligands with arsenic(III). In continuation of our interest in studies on group 15 elements with sulphur ligands $17-11,16,24-26 /$, we report herein some new mixed his(dialkyldithiocarbamato)arsenic(III) complexes with alkyldithiocarbonates of the type $\left[\mathrm{R}_{2} \mathrm{NCS}_{2}\right]_{2} \mathrm{AsS}_{2} \mathrm{COR}^{\prime}$ [where, $\mathrm{R}=\mathrm{CH}_{3}$ and $\mathrm{C}_{2} \mathrm{H}_{5} ; \mathrm{R}^{\prime}=\mathrm{Et}, \mathrm{Pr}^{\mathrm{n}}, \mathrm{Pr}^{\prime}, \mathrm{Bu}^{\mathrm{n}}$ and $\mathrm{Bu}^{\mathrm{i}}$ ]. 


\section{EXPERIMENTAL}

\section{Materials and Methods}

All the experiments were carried out under moisture free conditions. Solvents (benzene, alcohols, hexane, carbon disulphide, diethylether and dichloromethane etc.) were purified and dried by standard methods $/ 27 /$. Sodium salt of dimethyldithiocarbamate (Fluka), sodium salt of diethyldithiocarbamate (BDH), arsenic trioxide (Merck) were used as received without further purification. Thionyl chloride (Merck) was distilled before use.

The alkyldithiocarbonates/28/, tris(dialkyldithiocarbamato)arsenic(III)/12/ and bis(dialkyldithiocarbamato)arsenic(III) chloride /12/ were prepared by reported methods. Arsenic trichloride was prepared by the reaction of arsenic trioxide and thionyl chloride $29 /$. Sulphur was determined gravimetrically as barium sulphate $/ 30$. Arsenic was determined iodometrically $/ 31 \%$.

Melting points were determined on B10 Tech India Melting Apparatus and are uncorrected. Elemental analysis $(\mathrm{C}, \mathrm{H}$ and $\mathrm{N}$ ) was performed on a Heraeus Carlo Erba $1108 \mathrm{C}, \mathrm{H}, \mathrm{N}$ analyzer. Infrared spectra were recorded on Perkin Elmer Model 557 as $\mathrm{KBr}$ disc in the range $4000-200 \mathrm{~cm}^{-1}$. ' $\mathrm{H}$ and ${ }^{13} \mathrm{C}$ NMR spectra were recorded in $\mathrm{CDCl}_{3}$ solutions on Bruker DRX300 (300 MHz FT NMR) spectrometers; chemical shift values ${ }^{1} \mathrm{H}$ and ${ }^{13} \mathrm{C}$ are expressed in $\delta$ ppm relative to TMS.

\section{Preparation of bis(diethyldithiocarbamato)arsenic(III) isopropyldithiocarbonate}

Equimolar amounts of bis(diethyldithiocarbamato)arsenic(III) chloride $(1.10 \mathrm{~g}, 2.70 \mathrm{mmol})$ and potassium salt of isopropyldithiocarbonate $(0.47 \mathrm{~g}, 2.70 \mathrm{mmol})$ in anhydrous benzene and carbondisulphide mixture $(1: 1)$ were stirred for $\sim 4$ hours at room temperature. Precipitated potassium chloride $(0.19 \mathrm{~g})$ was removed by filtration. Filtrate was concentrated to $\sim 5 \mathrm{ml}$ under reduced pressure. The yellow viscous liquid thus obtained was crystallized by adding 4-5 drops of anhydrous hexane and keeping it overnight in a refrigerator; the pale yellow solid thus obtained was dried on a vacuum pump. Yield - $1.08 \mathrm{~g} ; 79 \%$; M.P. $70^{\circ} \mathrm{C}$ (Table I). All the other derivatives were prepared by adopting the above methods. Pertinent analytical and physicochemical data for these complexes are listed in (Table l).

\section{RESULTS AND DISCUSSION}

Bis(dialkyldithiocarbainato)arsenic(III) alkyldithiocarbonate derivatives have been synthesised by reacting bis(dialkyldithiocarbamato)arsenic(III) chloride with potassium salts of alkyldithiocarbonate in equimolar ratios in anhydrous benzene and carbondisulphide $(1: 1)$ mixture by stirring at room temperature for $\sim 4$ hours.

$$
\begin{gathered}
{\left[\mathrm{R}_{2} \mathrm{NCS}_{2}\right]_{2} \mathrm{AsCl}+\mathrm{KS}_{2} \mathrm{COR}, \stackrel{\text { Benzene }+\mathrm{CS}_{2}}{\longrightarrow}\left[\mathrm{R}_{2} \mathrm{NCS}_{2}\right]_{2} \mathrm{AsS}_{2} \mathrm{COR}^{\prime}+\mathrm{KCl} \downarrow} \\
\text { (where, } \mathrm{R}=\mathrm{CH}_{3} \text { and } \mathrm{C}_{2} \mathrm{H}_{5} ; \mathrm{R}^{\prime}=\mathrm{Et}, \mathrm{Pr}^{\mathrm{n}}, \mathrm{Pr}^{\prime}, \mathrm{Bu}^{\mathrm{n}} \text { and } \mathrm{Bu}^{\prime} \text { ) }
\end{gathered}
$$




\begin{tabular}{|c|c|c|c|c|c|c|c|c|c|c|c|}
\hline \multirow{5}{*}{ 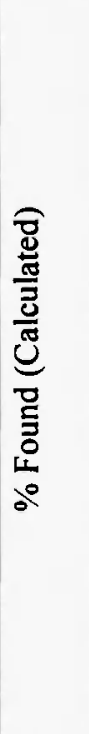 } & $\mathbf{z}$ & $\begin{array}{ll}\overline{0} & \widehat{f} \\
0 & 0 \\
0\end{array}$ & 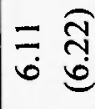 & 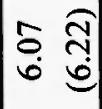 & 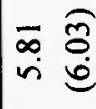 & 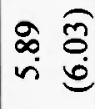 & \begin{tabular}{ll}
\multirow{n}{*}{} & $\widehat{0}$ \\
$\sim$ & 0 \\
$\sim$ & 0
\end{tabular} & $\begin{array}{l}\overline{0} \\
\stackrel{n}{n} \\
\end{array}$ & 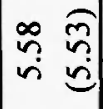 & 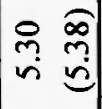 & $\begin{array}{ll}m & 0 \\
\dot{m} & m \\
\dot{n}\end{array}$ \\
\hline & $I$ & 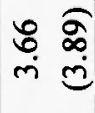 & $\stackrel{\infty}{\underset{+}{\mathbb{*}}}$ & 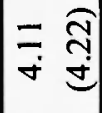 & $\underset{\sim}{\nabla}$ & $\stackrel{\tilde{m}}{\widetilde{\sigma}}$ & $\begin{array}{ll}\infty & \widehat{\sigma} \\
\dot{\sigma} & 0\end{array}$ & 年 & 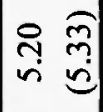 & 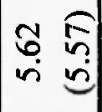 & 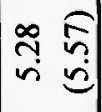 \\
\hline & ن & 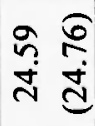 & 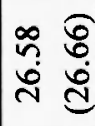 & $\mid \begin{array}{ll}8 & 8 \\
0 & 8 \\
0 & 0 \\
\sim & 0\end{array}$ & 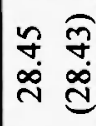 & 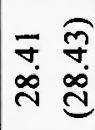 & $\frac{g}{\bar{m}} \frac{\hat{\sigma}}{0}$ & 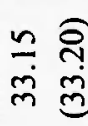 & 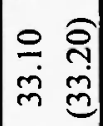 & $\begin{array}{ll}\tilde{n} & \overline{8} \\
\dot{m} & \dot{0} \\
\dot{m} & \stackrel{0}{0}\end{array}$ & $\begin{array}{ll}0 & \overline{8} \\
\sim & \\
\dot{+} & \stackrel{0}{0}\end{array}$ \\
\hline & $n$ & 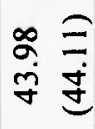 & 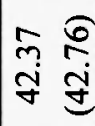 & 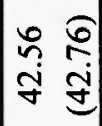 & 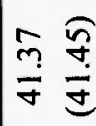 & ๗ֶ? & $\begin{array}{ll}\sim & \widehat{O} \\
\infty & 0 \\
\infty & 0\end{array}$ & 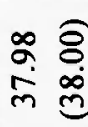 & $\mid \begin{array}{ll}\infty & 8 \\
\infty & 8 \\
\dot{\infty} & \infty \\
m & 0\end{array}$ & 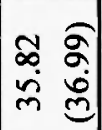 & $\begin{array}{ll}\infty & \widehat{\Omega} \\
0 & \Omega \\
0 & 0 \\
m & 0\end{array}$ \\
\hline & 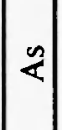 & 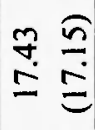 & $\begin{array}{l}\infty \\
\stackrel{\infty}{0} \\
\stackrel{0}{0} \\
0\end{array}$ & $\mid \begin{array}{ll}\infty & \widehat{\sigma} \\
0 & 0 \\
0 & 0 \\
- & 0\end{array}$ & $\frac{0}{0}$ & 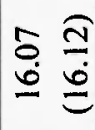 & 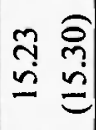 & 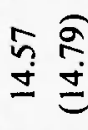 & 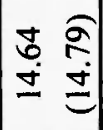 & 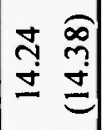 & 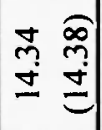 \\
\hline 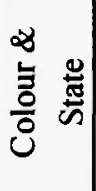 & & 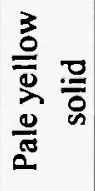 & 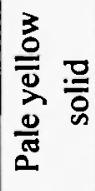 & 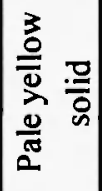 & 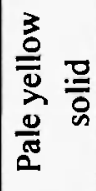 & 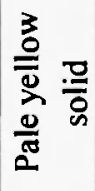 & 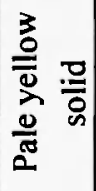 & $\begin{array}{l}\frac{3}{0} \\
\frac{0}{\bar{D}} \\
\frac{0}{2} \\
\frac{0}{0} \\
\frac{0}{0}\end{array}$ & 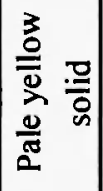 & 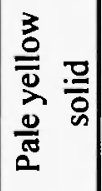 & 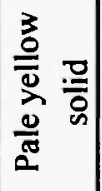 \\
\hline$\sum_{0}^{0}$ & & $\underline{I}$ & 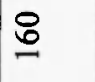 & $\widetilde{N}$ & $\approx$ & $\bar{v}$ & $\hat{0}$ & $\hat{0}$ & 요 & $\nabla$ & $\Xi$ \\
\hline $\begin{array}{cc}\bar{U} & \bar{\Xi} \\
\forall & \overline{\mathbf{L}} \\
\end{array}$ & 它 & 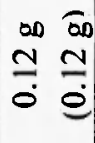 & 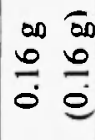 & $\begin{array}{ll}\text { in } & 0 \\
n & n \\
0 & 0\end{array}$ & 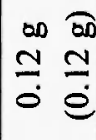 & $\begin{array}{ll}\text { on } & 00 \\
m & \frac{m}{9} \\
0 & 0\end{array}$ & $\begin{array}{ll}\frac{\infty}{00} \\
& \frac{1}{e} \\
0\end{array}$ & 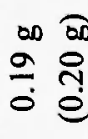 & 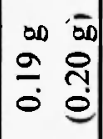 & 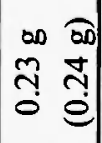 & 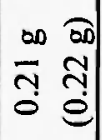 \\
\hline$\stackrel{0}{\circ} \stackrel{0}{2}$ & & $\widetilde{\infty}$ & $\infty$ & $\infty$ & 8 & 8 & $\infty$ & $\bar{\sigma}$ & 9 & $\vec{\infty}$ & $\infty$ \\
\hline 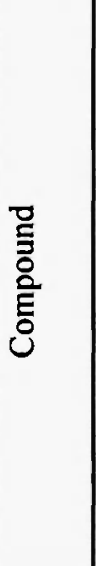 & & 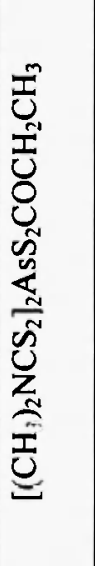 & 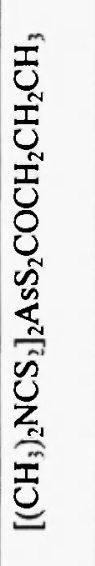 & 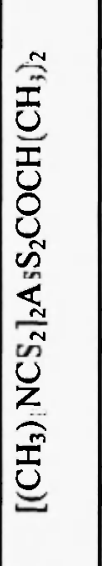 & 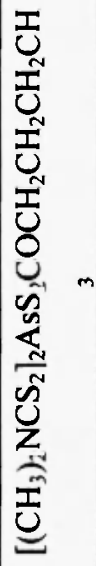 & 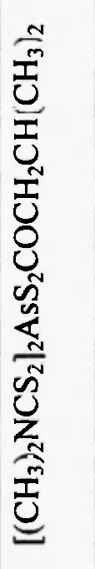 & 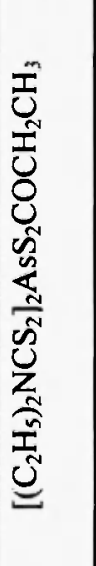 & 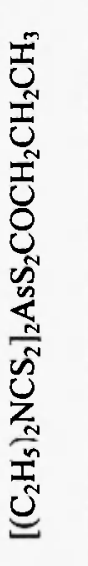 & 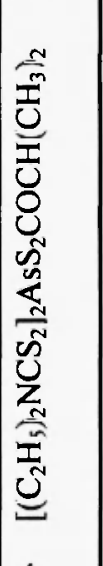 & 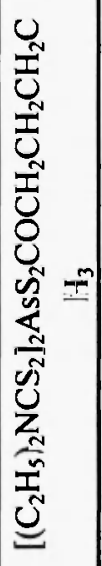 & 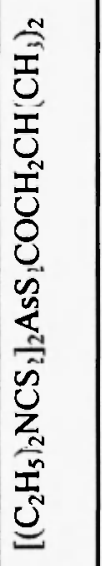 \\
\hline 0 z & & $\dot{-}$ & N & $\dot{m}$ & $\dot{\nabla}$ & in & $0^{\circ}$ & $\therefore$ & $\infty$ & $\sigma^{\circ}$ & $\stackrel{\circ}{ }$ \\
\hline
\end{tabular}


All these newly synthesized derivatives are pale yellow solids. All these derivatives are soluble in common organic solvents like benzene, chloroform, carbondisulphide, acetone and dichloromethane, etc. The elemental analysis are also in accordance with their molecular formulae.

\section{Infra-red Spectra}

IR spectra of all these newly synthesised compounds have been recorded as $\mathrm{KBr}$ disc in the range 4000 $200 \mathrm{~cm}^{-1}$ and tentative assignments of the important characteristic bands have been made with the help of earlier publications $/ 7-11,24-26 /$.

The spectra of arsenic(III) dithiocarbonate derivatives exhibit very strong absorption bands in the regions $1225-1240 \mathrm{~cm}^{-1}$ and $1150-1170 \mathrm{~cm}^{-1}$ due to $(\mathrm{C}-\mathrm{O}-\mathrm{C})$ and $(\mathrm{C}-\mathrm{O})$ stretching vibration, respectively. All these complexes show medium to strong intensity absorption bands in the region $1020-1040 \mathrm{~cm}^{-1}$ due to $(\mathrm{C}=\mathrm{S})$ stretching vibrations of both dialkyldithiocarbamate as well as alkyldithiocarbonate moieties indicating the bidentate nature of the both dialkyldithiocarbamate and alkyldithiocarbonate moieties with arsenic. All these derivatives also show medium to strong intensity absorption bands in the region $1425-$ 1520 and $320-325 \mathrm{~cm}^{-1}$ due to $(C=N)$ and (As-S) stretching vibrations, respectively.

\section{'H NMR}

The 'H NMR spectra of bis(dialkyldithiocarbamato)arsenic(III) complexes with alkyldithiocarbonates have been recorded in $\mathrm{CDCl}_{3}$ solutions using TMS as an internal standard.

In the corresponding dimethyldithiocarbamate derivatives, the methyl protons appear as a singlet at 3.39$3.43 \mathrm{\delta pm}$ thus suggesting the magnetic equivalence of these protons, while the diethyldithiocarbamate derivatives exhibit a triplet at $0.64-0.81 \mathrm{\delta ppm}$ and a quartet at 3.16-3.35 $\mathrm{\delta ppm}$ due to $\mathrm{CH}_{3}$ and $\mathrm{CH}_{2}$ proton resonances, respectively (Table II).

In addition, these alkyldithiocarbonate derivatives also show expected proton resonances due to alkoxy protons of dithiocarbonate moieties /18-20\%. The ethyl protons in ethyldithiocarbonate derivatives (Compound No.1 and 6; Table II) appear as a triplet and quartet at $1.40 \delta \mathrm{ppm}$ and $4.62 \delta \mathrm{ppm}$ due to $\mathrm{CH}_{3}$ and $\mathrm{OCH}_{2}$ proton resonances, respectively for the Compound No.I (Table II), while for the Compound No.6 (Table II) the $\mathrm{CH}_{3}$ protons of dithiocarbamate moieties and dithiocarbonate moieties are overlapping and exhibit a set of complex pattern signals in the range $0.64-0.78 \delta \mathrm{ppm}$ and a quartet at $4.16 \delta \mathrm{ppm}$ due to $\mathrm{OCH}_{2}$ proton resonances. The n-propyldithiocarbonate derivatives (Compound No.2 and 7; Table II) appear as triplet at $0.74-0.96 \mathrm{spm}$ due to $\mathrm{CH}_{3}$ protons, multiplet at $1.74-3.38 \mathrm{\delta pm}$ due to middle $\mathrm{CH}_{2}$ protons 


\section{Table II}

${ }^{1} \mathrm{H},{ }^{13} \mathrm{C}$ and ${ }^{31} \mathrm{P}$ NMR spectral data (8ppm) of bis(dialkyldithiocarbamato)arsenic(III) complexes with alkyldithiocarbonates

\begin{tabular}{|c|c|c|c|}
\hline $\begin{array}{c}\text { C.N } \\
\text { o. }\end{array}$ & Compound & 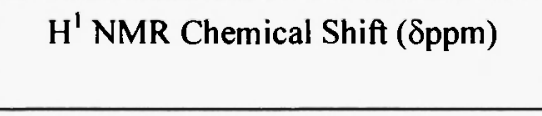 & $\begin{array}{c}{ }^{13} \mathrm{C} \text { NMR Chemical Shift } \\
(\delta \mathrm{ppm})\end{array}$ \\
\hline 1. & {$\left[\left(\mathrm{CH}_{3}\right)_{2} \mathrm{NCS}_{2}\right]_{2} \mathrm{AsS}_{2} \mathrm{COCH}_{2} \mathrm{CH}_{3}$} & $\begin{array}{l}1.40, \mathrm{t}, 3 \mathrm{H}\left(\mathrm{CH}_{3} \text { of xan }\right) \\
\mathrm{J}=6.00 \mathrm{~Hz} \\
3.43, \mathrm{~s}, 12 \mathrm{H}\left(\mathrm{CH}_{3} \text { of dtc }\right) \\
4.62, \mathrm{q}, 2 \mathrm{H}\left(\mathrm{OCH}_{2} \text { of xan }\right) \\
\mathrm{J}=6.00 \mathrm{~Hz}\end{array}$ & $\begin{array}{l}0.93\left(\mathrm{CH}_{3} \text { of } x a n\right) \\
43.10\left(\mathrm{CH}_{3} \text { of dtc }\right) \\
70.44\left(\mathrm{OCH}_{2} \text { of } x a n\right) \\
192.8\left(\mathrm{NCS}_{2} \text { of dtc }\right) \\
216.1\left(\mathrm{OCS}_{2} \text { of } x a n\right) \\
\end{array}$ \\
\hline 2. & {$\left[\left(\mathrm{CH}_{3}\right)_{2} \mathrm{NCS}_{2}\right]_{2} \mathrm{AsS}_{2} \mathrm{COCH}_{2} \mathrm{CH}_{2} \mathrm{CH}_{3}$} & $\begin{array}{l}0.96, \mathrm{t}, 3 \mathrm{H}\left(\mathrm{CH}_{3} \text { of } x a n\right) \\
\mathrm{J}=6.00 \mathrm{~Hz} \\
1.74-1.82, \mathrm{~m}, 2 \mathrm{H}\left(\mathrm{CH}_{2} \text { of } x a n\right) \\
3.42, \mathrm{~s}, 12 \mathrm{H}\left(\mathrm{CH}_{3} \text { of dtc }\right) \\
4.49, \mathrm{t}, 2 \mathrm{H}\left(\mathrm{OCH}_{2} \text { of } x a n\right) \\
\mathrm{J}=6.00 \mathrm{~Hz}\end{array}$ & $\begin{array}{l}10.37\left(\mathrm{CH}_{3} \text { of } x a n\right) \\
21.67\left(\mathrm{CH}_{2} \text { of } x a n\right) \\
43.14\left(\mathrm{CH}_{3} \text { of } \mathrm{dtc}\right) \\
74.9\left(\mathrm{OCH}_{2} \text { of } x a n\right) \\
192.8\left(\mathrm{NCS}_{2} \text { of dtc }\right) \\
216.7\left(\mathrm{OCS}_{2} \text { of } x a n\right)\end{array}$ \\
\hline 3. & {$\left[\left(\mathrm{CH}_{3}\right)_{2} \mathrm{NCS}_{2}\right]_{2} \mathrm{AsS}_{2} \mathrm{COCH}\left(\mathrm{CH}_{3}\right)_{2}$} & $\begin{array}{l}1.34, \mathrm{~d}, 6 \mathrm{H}\left(\mathrm{CH}_{3} \text { of } x a n\right) \\
\mathrm{J}=6.00 \mathrm{~Hz} \\
3.39, \mathrm{~s}, 12 \mathrm{H}\left(\mathrm{CH}_{3} \text { of dtc }\right) \\
5.62, \mathrm{sep}, 1 \mathrm{H}(\mathrm{OCH} \text { of } x a n) \\
\mathrm{J}=6.00 \mathrm{~Hz}\end{array}$ & $\begin{array}{l}0.8\left(\mathrm{CH}_{3} \text { of xan }\right) \\
43.0\left(\mathrm{CH}_{3} \text { of dtc }\right) \\
79.2(\mathrm{OCH} \text { of } x a n) \\
198.2\left(\mathrm{NCS}_{2} \text { of } \mathrm{dtc}\right) \\
217.0\left(\mathrm{OCS}_{2} \text { of } x a n\right) \\
\end{array}$ \\
\hline 6. & {$\left[\left(\mathrm{C}_{2} \mathrm{H}_{5}\right)_{2} \mathrm{NCS}_{2}\right]_{2} \mathrm{AsS}_{2} \mathrm{COCH}_{2} \mathrm{CH}_{3}$} & $\begin{array}{l}0.64-0.78, \mathrm{~m}, 15 \mathrm{H} \\
\left(\mathrm{CH}_{3} \text { of dtc and xan }\right) \\
3.16, \mathrm{q}, 8 \mathrm{H}\left(\mathrm{CH}_{2} \text { of dtc }\right) \\
\mathrm{J}=6.00 \mathrm{~Hz} \\
4.16, \mathrm{q}, 2 \mathrm{H}\left(\mathrm{OCH}_{2} \text { of } x a n\right) \\
\mathrm{J}=6.00 \mathrm{~Hz}\end{array}$ & $\begin{array}{l}12.6\left(\mathrm{CH}_{3} \text { of dtc }\right) \\
14.0\left(\mathrm{CH}_{3} \text { of } x a n\right) \\
48.2\left(\mathrm{CH}_{2} \text { of } \mathrm{dtc}\right) \\
78.8\left(\mathrm{OCH}_{2} \text { of } x \mathrm{an}\right) \\
198.8\left(\mathrm{NCS}_{2} \text { of dtc }\right) \\
217.8\left(\mathrm{OCS}_{2} \text { of } x a n\right)\end{array}$ \\
\hline 7. & {$\left[\left(\mathrm{C}_{2} \mathrm{H}_{5}\right)_{2} \mathrm{NCS}_{2}\right]_{2} \mathrm{AsS}_{2} \mathrm{COCH}_{2} \mathrm{CH}_{2} \mathrm{CH}_{3}$} & $\begin{array}{l}0.64, \mathrm{t}, 12 \mathrm{H}\left(\mathrm{CH}_{3} \text { of dtc }\right) \mathrm{J}=6.0 \mathrm{~Hz} \\
0.74, \mathrm{t}, 3 \mathrm{H}\left(\mathrm{CH}_{3} \text { of xan }\right) \mathrm{J}=7.0 \mathrm{~Hz} \\
3.35, \mathrm{q}, 8 \mathrm{H}\left(\mathrm{CH}_{2} \text { of dtc }\right) \mathrm{J}=6.0 \mathrm{~Hz} \\
3.30-3.38, \mathrm{~m}, 2 \mathrm{H}\left(\mathrm{CH}_{2} \text { of xan }\right) \\
4.19, \mathrm{t}, 2 \mathrm{H}\left(\mathrm{OCH}_{2} \text { of xan }\right) \mathrm{J}=7.0 \mathrm{~Hz}\end{array}$ & $\begin{array}{l}10.49\left(\mathrm{CH}_{3} \text { of } x a n\right) \\
11.26\left(\mathrm{CH}_{3} \text { of } \mathrm{dtc}\right) \\
20.39\left(\mathrm{CH}_{2} \text { of } \mathrm{xan}\right) \\
42.26\left(\mathrm{CH}_{2} \text { of } \mathrm{dtc}\right) \\
76.33\left(\mathrm{OCH}_{2} \text { of } \mathrm{xan}\right) \\
192.8\left(\mathrm{NCS}_{2} \text { of } \mathrm{dtc}\right) \\
216.0\left(\mathrm{OCS}_{2} \text { of } x a n\right)\end{array}$ \\
\hline
\end{tabular}




\begin{tabular}{|c|c|c|c|}
\hline 8. & {$\left[\left(\mathrm{C}_{2} \mathrm{H}_{5}\right)_{2} \mathrm{NCS}_{2}\right]_{2} \mathrm{AsS}_{2} \mathrm{COCH}\left(\mathrm{CH}_{3}\right)_{2}$} & $\begin{array}{l}0.81, \mathrm{t}, 12 \mathrm{H}\left(\mathrm{CH}_{3} \text { of dtc }\right) \mathrm{J}=7.0 \mathrm{~Hz} \\
1.00, \mathrm{~d}, 6 \mathrm{H}\left(\mathrm{CH}_{3} \text { of xan }\right) \mathrm{J}=6.0 \mathrm{~Hz} \\
3.25, \mathrm{q}, 8 \mathrm{H}\left(\mathrm{CH}_{2} \text { of dtc }\right) \mathrm{J}=7.0 \mathrm{~Hz} \\
5.58, \operatorname{sep}, 1 \mathrm{H}(\mathrm{OCH} \text { of xan }) \\
\mathrm{J}=6.0 \mathrm{~Hz}\end{array}$ & $\begin{array}{l}12.31\left(\mathrm{CH}_{3} \text { of } \mathrm{dtc}\right) \\
13.68\left(\mathrm{CH}_{3} \text { of } \mathrm{xan}\right) \\
48.41\left(\mathrm{CH}_{2} \text { of } \mathrm{dtc}\right) \\
78.6(\mathrm{OCH} \text { of } \mathrm{xan}) \\
198.8\left(\mathrm{NCS}_{2} \text { of } \mathrm{dtc}\right) \\
217.8\left(\mathrm{OCS}_{2} \text { of } \mathrm{xan}\right)\end{array}$ \\
\hline 9. & {$\left[\left(\mathrm{C}_{2} \mathrm{H}_{5}\right)_{2} \mathrm{NCS}_{2}\right]_{2} \mathrm{AsS}_{2} \mathrm{COCH}_{2} \mathrm{CH}_{2} \mathrm{CH}_{2} \mathrm{CH}_{3}$} & $\begin{array}{l}0.68, \mathrm{t}, 12 \mathrm{H}\left(\mathrm{CH}_{3} \text { of dtc }\right) \mathrm{J}=6.0 \mathrm{~Hz} \\
0.76, \mathrm{t}, 6 \mathrm{H}\left(\mathrm{CH}_{3} \text { of xan }\right) \mathrm{J}=6.0 \mathrm{~Hz} \\
0.98-1.10, \mathrm{~m}, 2 \mathrm{H}\left(\mathrm{CH}_{2} \mathrm{CH}_{3} \text { of xan }\right) \\
1.29-1.38, \mathrm{~m}, 2 \mathrm{H}\left(\mathrm{CH}_{2} \mathrm{CH}_{2} \text { of xan }\right) \\
3.25, \mathrm{q}, 8 \mathrm{H}\left(\mathrm{CH}_{2} \text { of dtc }\right) \mathrm{J}=6.0 \mathrm{~Hz} \\
4.32, \mathrm{t}, 2 \mathrm{H}\left(\mathrm{OCH}_{2} \text { of xan }\right) \mathrm{J}=6.0 \mathrm{~Hz}\end{array}$ & $\begin{array}{l}12.03\left(\mathrm{CH}_{3} \text { of } \mathrm{dtc}\right) \\
14.1\left(\mathrm{CH}_{3} \text { of xan }\right) \\
18.9\left(\mathrm{CH}_{2} \text { of } \mathrm{xan}\right) \\
41.0\left(\mathrm{CH}_{2} \text { of } \mathrm{dtc}\right) \\
46.7\left(\mathrm{CH}_{2} \text { of } \mathrm{xan}\right) \\
74.43\left(\mathrm{OCH}_{2} \text { of xan }\right) \\
192.8\left(\mathrm{NCS}_{2} \text { of dtc }\right) \\
217.3\left(\mathrm{OCS}_{2} \text { of xan }\right)\end{array}$ \\
\hline 10. & {$\left[\left(\mathrm{C}_{2} \mathrm{H}_{5}\right)_{2} \mathrm{NCS}_{2}\right]_{2} \mathrm{AsS}_{2} \mathrm{COCH}_{2} \mathrm{CH}\left(\mathrm{CH}_{3}\right)_{2}$} & $\begin{array}{l}0.63-0.72, \mathrm{~m}\left(\mathrm{CH}_{3} \text { of dtc }+ \text { xan }\right) \\
1.68-1.80, \mathrm{~m}, \mathrm{l} \mathrm{H}(\mathrm{CH} \text { of xan }) \\
3.26, \mathrm{q}, 8 \mathrm{H}\left(\mathrm{CH}_{2} \text { of dtc }\right) \mathrm{J}=7.0 \mathrm{~Hz} \\
4.16, \mathrm{~d}, 2 \mathrm{H}\left(\mathrm{OCH}_{2} \text { of xan }\right) \mathrm{J}=6.0 \mathrm{~Hz}\end{array}$ & $\begin{array}{l}11.8\left(\mathrm{CH}_{3} \text { of } \mathrm{dtc}\right) \\
14.1\left(\mathrm{CH}_{3} \text { of } x a n\right) \\
32.5(\mathrm{CH} \text { of } \mathrm{xan}) \\
49.1\left(\mathrm{CH}_{2} \text { of } \mathrm{dtc}\right) \\
75.6\left(\mathrm{OCH}_{2} \text { of } \mathrm{xan}\right) \\
198.8\left(\mathrm{NCS}_{2} \text { of } \mathrm{dtc}\right) \\
216.2\left(\mathrm{OCS}_{2} \text { of } \mathrm{xan}\right)\end{array}$ \\
\hline
\end{tabular}

$\mathbf{s}=$ singlet, $d=$ doublet, $\mathbf{t}=$ triplet, $\mathbf{q}=$ quartet, $\mathbf{m}=$ =multiplet, $\operatorname{sep}=$ =septet

and a triplet at 4.19-4.49 $\delta \mathrm{ppm}$ due to $\mathrm{OCH}_{2}$ proton resonances, respectively. The i-propyldithiocarbonate derivatives (Compound No. 3 and 8; Table II) show doublet and septet in the region $1.00-1.34$ and $5.58-$ $5.62 \delta \mathrm{ppm}$ due to $\mathrm{CH}_{3}$ and $\mathrm{OCH}$ proton resonances, respectively. The $n$-butyldithiocarbonate derivative (Compound No. 9; Table II) show triplet at $0.76 \mathrm{\delta pm}$ due to $\mathrm{CH}_{3}$ protons, multiplet in the region 0.98-1.10 Sppm due to $\mathrm{CH}_{2}$ attached to $\mathrm{CH}_{3}$ protons, multiplet in the region 1.29-1.38 $8 \mathrm{ppm}$ due to $\mathrm{CH}_{2}$ attached to $\mathrm{OCH}_{2}$ protons and a triplet at $4.32 \mathrm{\delta ppm}$ due to $\mathrm{OCH}_{2}$ proton resonances, respectively. The ibutyldithiocarbonate derivative (Compound No. 10; Table II) shows multiplet at $0.63-0.72$ due to overlapping of $\mathrm{CH}_{3}$ protons of dithiocarbamate and dithiocarbonate moieties as well as a multiplet and a doublet in the range $1.68-1.80$ and $4.16 \delta \mathrm{ppm}$ due to middle $\mathrm{CH}$ and $\mathrm{OCH}_{2}$ proton resonances, respectively.

\section{${ }^{13}$ C NMR}

The proton decoupled ${ }^{13} \mathrm{C}$ NMR spectra (Table II) of these compounds have been recorded in $\mathrm{CDCl}_{3}$ solutions using TMS as an internal standard. The ${ }^{13} \mathrm{C}$ NMR signals thus obtained are at reported values 
without any appreciable shifts. The proton decoupled ${ }^{13} \mathrm{C}$ NMR spectra of the dimethyldithiocarbamate complexes show a signal in the region $43.0-43.14 \delta \mathrm{ppm}$ due to magnetic equivalent methyl carbon. The complexes of diethyldithiocarbamate show two signals, one at 11.26-12.6 $\delta \mathrm{ppm}$ and the other at $41.0-49.1$ $\delta \mathrm{ppm}$ due to $\mathrm{CH}_{3}$ and $\mathrm{CH}_{2}$ carbons, respectively. All these compounds show a signal at $192.8-198.8 \mathrm{\delta ppm}$ due to $\mathrm{NCS}_{2}$ carbon resonances of dialkyldithiocarbamate moieties.

In addition, these alkyldithiocarbonate derivatives also exhibit signals due to alkoxy carbons of dithiocarbonate moieties. The ethyldithiocarbonate derivatives (Compound No. 1 and 6; Table II) exhibit signals at $0.93-14.0$ and $70.44-78.8$ and $\delta p p m$ due to $\mathrm{CH}_{3}$ and $\mathrm{OCH}_{2}$ carbon resonance, respectively. The n-propyldithiocarbonate derivatives (Compound No. 2 and 7; Table II) exhibit signals at 10.37-10.49, 20.3921.67 and 74.90-76.33 $8 \mathrm{ppm}$ due to $\mathrm{CH}_{3}, \mathrm{CH}_{2}$ and $\mathrm{OCH}_{2}$ carbon resonances, respectively. The ipropyldithiocarbonate derivatives (Compound No. 3 and 8, Table II) exhibit signals at 0.80-13.68 and 78.6$79.28 \mathrm{ppm}$ due to $\mathrm{CH}_{3}$ and $\mathrm{OCH}$ carbon resonances, respectively. The n-butyldithiocarbonate derivatives (Compound No. 9, Table II) exhibit signals at $14.1,18.9,46.7$ and $74.43 \mathrm{\delta ppm}$ due to $\mathrm{CH}_{3}, \mathrm{CH}_{2}$ (attached to $\mathrm{CH}_{3}$ ), $\mathrm{CH}_{2}$ (attached to $\mathrm{OCH}_{2}$ ) and $\mathrm{OCH}_{2}$ carbon resonances, respectively. The isobutyldithiocarbonate derivatives (Compound No. 10, Table II) exhibit signals at $11.8,14.1,32.5,49.1$ and $75.6 \mathrm{spm}$ due to $\mathrm{CH}_{3}$, $\mathrm{CH}$ and $\mathrm{OCH}_{2}$ carbon resonances, respectively. All these compounds show signals of comparatively weak intensities in the region 216.0-217.8 $8 \mathrm{ppm}$ due to $\mathrm{OCS}_{2}$ carbon resonances of alkyldithiocarbonate moieties.

\section{STRUCTURAL ELUCIDATION}

Although it is quite difficult to comment on the molecular structure of these complexes in solid state without actual X-ray crystal structure analysis of at least one of the products, however, two distinct signals in the region $1020-1040 \mathrm{~cm}^{-1}$ due to $(\mathrm{C}-\mathrm{\cdots}$. S) stretching vibrations of dialkyldithiocarbamates as well as alkyldithiocarbonates in these bis(dialkyldithiocarbamato)arsenic(III) complexes with alkyldithiocarbonate derivatives indicate the weakly anisobidentate nature of both dithiocarbamate and dithiocarbonate ligands. On the basis of the above spectral data it may be concluded tentatively that these ligands behave as anisobidentate mode of attachment to the metal where one of the sulphur atoms is weakly coordinated, thus leading to a distorted octahedral geometry, with a stereochemically active lone pair of electrons.

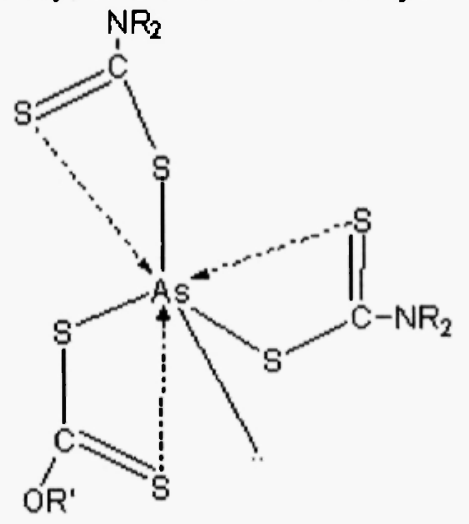

Proposed Structure of the Complexes

where, $\mathrm{X}=\mathrm{COR}{ }^{\prime}, \mathrm{R}=\mathrm{CH}_{3}$ and $\mathrm{C}_{2} \mathrm{H}_{5}, \mathrm{R}^{\prime}=\mathrm{Et}, \mathrm{Pr}^{\mathrm{n}}, \mathrm{Pr}^{\mathrm{i}}, \mathrm{Bu}^{\mathrm{n}}$ and $\mathrm{Bu}^{\prime}$. 


\section{ACKNOWLEDGEMENT}

Financial assistance from the University Grants Commission, New Delhi, is gratefully acknowledged. Elemental analyses as well as spectral studies were carried out at the Sophisticated Analytical Instrument Facility of the Central Drug Research Institute, Lucknow, India.

\section{REFERENCES}

1. R. Bally, Acta Crystallorg. 23, 295 (1967).

2. D. Coucouvanis, Prog. Inorg. Chem. 11, 233 (1970); 26, 301 (1979).

3. G.E. Manoussakis, M. Lalia-Kantouri and R.B. Huff, J. Inorg. Nucl. Chem 37, 2330 (1975).

4. G.E. Manoussakis, C.A. Tsipis and A.G. Christophides, Z. Anorg. Allg. Chem. 417, 235 (1975).

5. C.L. Raston and A.H. White, J. Chem. Soc. Dalton Trans. 791 (1976).

6. C. Burschka and M. Wieber, Z. Naturforsch. 34B, 1037 (1979).

7. S. Chourasia, B. Nahar and H.P.S. Chauhan, Phosphorus, Sulfur and Silicon 119, 77 (1996).

8. H.P.S. Chauhan and B. Nahar, Phosphorus, Sulfur and Silicon 128, 119 (1997).

9. H.P.S. Chauhan, S. Chourasia, B. Nahar and R.K. Singh, Phosphorus, Sulfur and Silicon 134/135, 345 (1998).

10. H.P.S. Chauhan, B. Nahar and R.K. Singh, Synth. React. Inorg. Met-Org. Chem. 28(9), 1541 (1998).

11. H.P.S. Chauhan, R.K. Singh and Kavita Kori, Main Group Metal Chemistry 25(8), 511 (2002).

12. C.L. Raston and A.H. White, J. Chem. Soc. Dalton Trans. 1975, 2425 and references therein.

13. R. Cea-Olivares, R.A. Toscano, M. Lopez and P. Garcia, Monatsh Chem. 124, 177 (1993); Heteroatom Chem. 4, 313 (1993).

14. R. Cea Olivares, R.A. Toscano, C. Silvestru, P. Garcia, M.L. Cardoso, G.B. Amador and H. Noth, J. Organomet. Chem. 493, 61 (1995).

15. S.S. Garje and V.K. Jain, Coord. Chem.Rev. 236, 35 (2002).

16. H.P.S. Chauhan, Coord. Chem. Rev. 173, 1 (1998).

17. V.K. Jain, Coord. Chem. Rev. 135, 809 (1994).

18. B.F. Hoskins, E.R.T. Tiekink and G. Winter, Inorg. Chim. Acta 99, 177 (1985).

19. M.R. Snow and E.R.T. Tiekink, Aust. J. Chem. 40, 743 (1987).

20. S.R. Rao, Xanthates and Related Compounds, Marcel Dekker, New York (1971).

21. C.A. Peri, Gazz. Chim. Ital. 89, 1315 (1959).

22. M. Nagasawa, K. Nagamizu, S. Imamia and T. Maeda, Ihara Agricultural Chemical Co. Ltd., Japan, $17,132(1960)$.

23. R.K. Gupta, A.K. Rai and R.C. Mehrotra, Indian J. Chem. 24A, 752 (1985).

24. H.P.S. Chauhan and S. Lunkad, Main Group Metal Chemistry 17(5), 313 (1994).

25. H.P.S. Chauhan, B. Porwal and R.K. Singh, Indian J. Chem. 39A, 880 (2000).

26. H.P.S. Chauhan, Kavita Kori and M.S. Nagulu, Main Group Metal Chemistry 25(11), 659 (2002). 
27. J.A. Riddick and W.B. Bunger, Techniques of Chemistry, Organic Solvents, 2nd edn., Wiley Interscience, New York (1970).

28. A.I. Vogel, Practical Organic Chemistry, Longmans Green, London, 664 (1978).

29. S. Chourasia, Ph.D. Thesis, Devi Ahilya University, Indore, India (1997).

30. Vogel's Textbook of Quantitative Chemical Analysis, $5^{\text {th }}$ Ed., Bath Press Ltd., Great Britain,490, 1989.

31. H.P.S. Chauhan, G. Srivastava and R.C. Mehrotra, Polyhedron 2(5), 359 (1983). 
